\title{
Development of Filters for a Thermoelectric Colorimeter
}

\author{
Sayeda H. Emara* and Ray P. Teele
}

(May 21, 1963)

\begin{abstract}
Filters have been designed for use with photocells and phototubes in tristimulus colorimeters, but because of the variation in spectral response of these detectors from one to the other, it has not been worthwhile to attempt to achieve the best possible duplication of the CIE tristimulus functions. In the case of a thermoelectric detector, however, the response is so nonselective that the same filter designs can be used with any thermopile.

The new filters permit CIE tristimulus functions and chromaticity coordinates to be obtained directly with reasonable ascuracy. Results obtained on a thermoelectric colorimeter for five standard filters are compared with tristimulus values obtained by computation from spectral transmittance data.
\end{abstract}

\section{Introduction}

Experience has shown that the results obtained in visual color measurements by a single observer are likely to differ from those of some other observer. For this reason, a number of observers must be used in order to obtain representative results. Furthermore, an observer using the equality-of-brightness method of photometry will change his criterion for photometric balance over a period of several days; some observers exhibit variation during a single day. If the properties of the normal average eye (CIE standard observer) can be reproduced in a completely physical instrument, these problems can be avoided. However, it is to be emphasized that physical color measurements must be made with high precision if they are to compare favorably with visual judgments of color, especially of small color difference. A colorimeter comparable to the eye of the standard observer in discrimination sensitivity must be capable of measuring tristimulus values, $X, Y, Z$, to at least one part in a thousand. For many years, the Bureau has been examining glasses and chemicals for possible use in physical colorimeters. It is more desirable to design tristimulus filters for use with a nonselective detector rather than a selective detector because such filters are not dependent on the useful life of an individual detector nor limited to a particular one.

No physical detector has been constructed which has the same relative response curve as the average human eye for radiant energy of different wavelengths. It is possible, however, to make a nonselective receiver, which indicates the amount of received energy per unit time independent of its wavelength throughout the visible spectrum. If we interpose between the source and such a receiver filters which duplicate the CIE tristimulus functions, we can then measure the tristimulus values and by

${ }^{*}$ Guest Worker at the NBS-On leave from Ein-Shams University, Cairo, Egypt. computation obtain the chromaticity coordinates without reference to human observers. Such filters would permit CIE tristimulus functions and chromaticity coordinates to be obtained directly. The object of the present work was to determine if such filters could be realized closely enough to determine these quantities with reasonable accuracy.

Numerous instruments have been proposed and many constructed for direct color measurement over the years. Ives (1915) [1] $]^{1}$ described a thermopile tristimulus colorimeter in which he made use of a spectrum selectively projected through a series of carefully cut templates in place of the filters employed in the more recent devices. Twyman and Perry (1930) [2] suggested that three filters duplicating the then proposed standard observer could be used in a photoelectric instrument. Guild (1934) [3] described an experimental model of a photoelectric tristimulus colorimeter. A few years later Winch and Palmer (1937) [4], Dresler and Frühling (1938) [5], and Barnes (1939) [6] described devices for the same purpose. Gibson (1936) [7] and Van den Akker (1937) [8] have discussed the problem of obtaining source-filter-photocell combinations giving the closest equivalence to the standard observer. Hunter (1942) [9] described a three-filter method for photoelectric tristimulus colorimetry which was successfully applied to the Hunter multipurpose reflectometer [10] to measure surface color. Several new instruments have been designed in recent years. However, the photosensitive elements in these colorimeters have been barrier-layer photocells as in the instruments of Barnes (1939) [6] and Hunter (1942) [9], phototubes in the devices described by Glasser and Troy (1952) [11] and Hunter (1958) [12], and multiplier phototubes in the instruments designed by Sziklai (1951) [13], Bentley (1951) [14], and Nimeroff and Wilson (1954) [15]. Only in the instrument described by Ives (1915) [1] was a thermopile used.

\footnotetext{
${ }_{1}$ Figures in brackets indicate the literature references at the end of this paper.
} 


\section{Filter Design}

The only parts of a colorimeter over which the designer can exercise much control are the filters used to modify the detector response to obtain the $\bar{x}, \bar{y}$, and $\bar{z}$ functions of the CIE standard observer. The $\bar{x}$ function is bimodal and therefore two filters are used; one designated $\bar{x}$-short represents the $\bar{x}$ function from 380 to $500 \mathrm{~nm}$ and the other, $\bar{x}$-long, the $\bar{x}$ function from 510 to $760 \mathrm{~nm}$. The components of these filters are usually absorbing solutions and glasses. Information on characteristics of various solutions and glass cells tested for photometric use is given in papers published by Ives and Kingsbury [16], [17], [18]. In this investigation, spectrophotometric curves of various solutions and glasses were made on a General Electric recording spectrophotometer. The data obtained on these filter components were used to compute the concentrations and thicknesses required to obtain a good fit for the spectral tristimulus values, $\bar{x}_{\lambda}, \bar{y}_{\lambda}, \bar{z}_{\lambda}$. Each of the filters designed contains as its components a solution, a cell, and two or more glasses.

\subsection{Solutions}

Chemicals used for preparation of solutions were labeled "analytical reagent quality" or "reagent quality." To prevent contamination from cork stoppers, glass-stoppered bottles were used as containers for all solutions.

The compositions of solutions used are as follows:

$$
\text { a. Solution I ( } \bar{x} \text {-short and } \bar{z})
$$

Cobalt ammonium sulphate

$$
\left(\mathrm{CoSO}_{4} \cdot\left(\mathrm{NH}_{4}\right)_{2} \mathrm{SO}_{4} \cdot 6 \mathrm{H}_{2} \mathrm{O}\right)
$$

Nickelous sulphate $\left(\mathrm{NiSO}_{4} \cdot 6 \mathrm{H}_{2} \mathrm{O}\right)$

$13.0 \mathrm{~g}$

Glacial acetic acid

$19.5 \mathrm{~g}$

Distilled water to make one liter of solution.

$$
\text { b. Solution II ( } \bar{x}-\text { long) }
$$

Copper sulphate $\left(\mathrm{CuSO}_{4} \cdot 5 \mathrm{H}_{2} \mathrm{O}\right)$

Ferric sulphate $\left(\mathrm{Fe}_{2}\left(\mathrm{SO}_{4}\right)_{3} \cdot 9 \mathrm{H}_{2} \mathrm{O}\right)$

$11.0 \mathrm{~g}$

Glacial acetic acid

$11.5 \mathrm{~g}$

Distilled water to make one liter of solution.

$$
\text { c. Solution III }(\bar{y})
$$

Potassium dichromate $\left(\mathrm{K}_{2} \mathrm{Cr}_{2} \mathrm{O}_{7}\right)$

Copper sulphate $\left(\mathrm{CuSO}_{4} \cdot 5 \mathrm{H}_{2} \mathrm{O}\right)$

$0.140 \mathrm{~g}$

Cobalt ammonium sulphate

$\left(\mathrm{CoSO}_{4} \cdot\left(\mathrm{NH}_{4}\right)_{2} \mathrm{SO}_{4} \cdot 6 \mathrm{H}_{2} \mathrm{O}\right)$

Sulphuric acid (1.835 sp gr)

$17.0 \mathrm{~g}$

$2.10 \mathrm{~g}$

$10 \mathrm{ml}$

Distilled water to make one liter of solution.

\subsection{Cells}

The filter accuracy obtained with solutions in cells depends in part on the spectral transmittance and uniformity of the cell. Cells having nonselective windows, closely parallel, and with close tolerances on window spacing are commercially available. Three identical cells with $1-\mathrm{mm}$ thick windows and 50-mm spacing were selected. Spectrophotometric measurements indicated that the windows were nonselective in transmittance from 380 to $780 \mathrm{~mm}$ except for variations less than 1.5 percent. The solutions I, II, and III prepared as described above were placed in cells I, II, and III, respectively.

\subsection{Glasses}

The specifications of the glasses which were selected are shown in table 1 .

TABLE 1. Glass components of the four tristimulus filters
No.

a (This thickness is about $5 \mathrm{~mm}$ as furnished by the manufacturer. This glass may no longer bo obtainable from Kopp Glass Co, but it is similar to Corning may no longer bo obtainable from Kopp Glass Co., but it is similar to Corning heat-absorbing glasses from 560 to $780 \mathrm{~mm}$ is very similar to that of copper sulheat-absorbing glasses from 560 to $780 \mathrm{~mm}$ is very similar to that of copper sul-
phate solution. Therefore, adjustment cf concentration coulf be used to compensate for individual differences in spectral transmittance of the glass; however, glass samples obtained from three manufacturers were found to be sufficiently similar that no change in solution concentration was required.

\subsection{Tristimulus}

Solution-cells and the glasses listed in table 1 are combined to provide tristimulus filters as follows:

$$
\text { a. } \bar{x} \text {-short Filter }
$$

Solution-cell I and glasses numbered 1, 2, and 5

$$
\text { b. } \bar{x} \text {-long Filter }
$$

Solution-cell II and glasses numbered 3 and 5 .

$$
\text { c. } \bar{y} \text { Filter }
$$

Solution-cell III and glasses numbered 4 and 5 . This filter design is a slight modification of the luminosity filter design by Gibson, Teele, and Keegan (1939) [19]. The use of heat-absorbing glass necessitated a reduction in copper sulphate and potassium dichromate and an increase in cobalt ammonium sulphate.

$$
\text { d. } \bar{z} \text { Filter }
$$

Solution-cell I and glasses numbered 1 and 5 .

\section{Filter Characteristics}

Spectral transmittance data for each of the four filters were obtained on a recording spectrophotometer [20], [21], [22]. Routine corrections for 100 percent, zero, and wave length scale were made [23] but additional corrections for inertia, slit width, and back reflectance were not made [24] since their total for these filters is less than the uncertainty of a single run on the spectrophotometer. The results 
obtained are summarized in table 2. For each filter, the first column gives the spectral transmittance, the second column gives the relative transmittance adjusted to have the same area as the CIE curve, and the third column gives the CIE data. For ease of comparison the data from columns two and three for each filter are shown in figures 1, 2, 3, and 4 . The transmittances less than 0.001 for the $\bar{z}$ colorimeter filter from 590 to $830 \mathrm{~nm}$ were found by remeasuring the three individual components of the filter on a wider range spectrophotometer after unexplained discrepancies turned up in the check of the performance of the colorimeter to be described presently.

For each colorimeter filter the sum of column three divided by the sum of column one gives the factor used to obtain the values in column two. These factors are also used to obtain the relative tristimulus values of any light source directly from the instrument readings. I.

$$
\begin{array}{llll}
X=2.560 & \mathrm{I}_{\overline{\text {-short }}} & +5.596 & \mathrm{I}_{\bar{x} \text {-long }}, \\
Y=2.033 & \mathrm{I}_{\bar{y}}, & & \\
Z=12.166 & \mathrm{I}_{\bar{z}}^{-}, & &
\end{array}
$$

Where the subscript for I corresponds with the particular colorimeter filter being used.

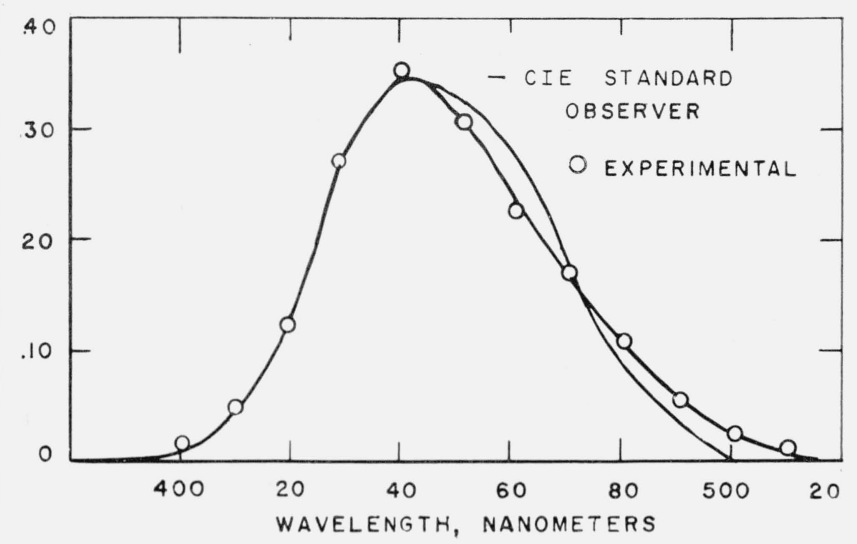

FIGURE 1. Adjusted transmittance of $\mathrm{x}$-short filter compared to CIE tristimulus values $\overline{\mathrm{x}}_{\lambda}$.

\begin{tabular}{|c|c|c|c|c|c|c|c|c|c|c|c|c|}
\hline \multirow{2}{*}{$\begin{array}{l}\text { Wave- } \\
\text { length }\end{array}$} & \multicolumn{3}{|c|}{$\bar{x}_{\text {-short }}$} & \multicolumn{3}{|c|}{$\bar{x}$-long } & \multicolumn{3}{|c|}{$\bar{y}$} & \multicolumn{3}{|c|}{$\bar{z}$} \\
\hline & $T$ & $2.5605 T$ & CIE & $T$ & $5.5963 T$ & CIE & $T$ & $2.0327 T$ & CIE & $T$ & $12.166 \mathrm{~T}$ & CIE \\
\hline $\begin{array}{l}n m \\
380 \\
390\end{array}$ & $\begin{array}{r}0.0005 \\
.0028\end{array}$ & $\begin{array}{r}0.0013 \\
.0072\end{array}$ & $\begin{array}{r}0.0014 \\
.0042\end{array}$ & & & & $\begin{array}{r}0.0000 \\
.0007\end{array}$ & $\begin{array}{r}0.0000 \\
.0014\end{array}$ & $\begin{array}{r}0.0000 \\
.0001\end{array}$ & $\begin{array}{r}0.0006 \\
.0034\end{array}$ & $\begin{array}{r}0.0073 \\
.0414\end{array}$ & $\begin{array}{r}0.0065 \\
.0201\end{array}$ \\
\hline $\begin{array}{l}400 \\
410 \\
420 \\
430 \\
440\end{array}$ & $\begin{array}{l}.0063 \\
.0173 \\
.0528 \\
.1079 \\
.1399\end{array}$ & $\begin{array}{l}.0161 \\
.0443 \\
.1352 \\
.2763 \\
.3582\end{array}$ & $\begin{array}{l}.0143 \\
.0435 \\
.1344 \\
.2839 \\
.3483\end{array}$ & & & & $\begin{array}{l}.0007 \\
.0007 \\
.0011 \\
.0030 \\
.0092\end{array}$ & $\begin{array}{l}.0014 \\
.0014 \\
.0022 \\
.0061 \\
.0187\end{array}$ & $\begin{array}{l}.0004 \\
.0012 \\
.0040 \\
.0116 \\
.0230\end{array}$ & $\begin{array}{l}.0074 \\
.0199 \\
.0608 \\
.1242 \\
.1623\end{array}$ & $\begin{array}{r}.0900 \\
.2421 \\
.7397 \\
1.5111 \\
1.9746\end{array}$ & $\begin{array}{r}.0679 \\
.2074 \\
.6456 \\
\text { 1. } 3856 \\
1.7471\end{array}$ \\
\hline $\begin{array}{l}450 \\
460 \\
470 \\
480 \\
490\end{array}$ & $\begin{array}{l}.1196 \\
.0900 \\
.0679 \\
.0443 \\
.0244\end{array}$ & $\begin{array}{l}.3062 \\
.2304 \\
.1739 \\
.1134 \\
.0625\end{array}$ & $\begin{array}{l}.3362 \\
.2908 \\
.1954 \\
.0956 \\
.0320\end{array}$ & $\begin{array}{r}0.0000 \\
.0016\end{array}$ & $\begin{array}{r}0.0000 \\
.0090\end{array}$ & & $\begin{array}{l}.0187 \\
.0297 \\
.0523 \\
.0731 \\
.1020\end{array}$ & $\begin{array}{l}.0380 \\
.0604 \\
.1063 \\
.1486 \\
.2073\end{array}$ & $\begin{array}{l}.0380 \\
.0600 \\
.0910 \\
.1390 \\
.2080\end{array}$ & $\begin{array}{l}.1414 \\
.1094 \\
.0872 \\
.0629 \\
.0394\end{array}$ & $\begin{array}{r}1.7203 \\
1.3310 \\
1.0609 \\
0.7652 \\
.4793\end{array}$ & $\begin{array}{r}1.7721 \\
1.6692 \\
1.2876 \\
0.8130 \\
.4652\end{array}$ \\
\hline $\begin{array}{l}500 \\
510 \\
520 \\
530 \\
540\end{array}$ & $\begin{array}{l}.0113 \\
.0048 \\
.0019 \\
.0007 \\
.0005\end{array}$ & $\begin{array}{l}.0289 \\
.0123 \\
.0049 \\
.0018 \\
.0013\end{array}$ & .0049 & $\begin{array}{l}.0046 \\
.0077 \\
.0121 \\
.0212 \\
.0414\end{array}$ & $\begin{array}{l}.0257 \\
.0431 \\
.0677 \\
.1186 \\
.2317\end{array}$ & $\begin{array}{r}0.0093 \\
.0633 \\
.1655 \\
.2904\end{array}$ & $\begin{array}{l}.1530 \\
.2437 \\
.3545 \\
.4250 \\
.4671\end{array}$ & $\begin{array}{l}.3110 \\
.4954 \\
.7206 \\
.8639 \\
.9495\end{array}$ & $\begin{array}{l}.3230 \\
.5030 \\
.7100 \\
.8620 \\
.9540\end{array}$ & $\begin{array}{l}.0209 \\
.0106 \\
.0053 \\
.0026 \\
.0021\end{array}$ & $\begin{array}{l}.2543 \\
.1289 \\
.0645 \\
.0316 \\
.0255\end{array}$ & $\begin{array}{l}.2720 \\
.1582 \\
.0782 \\
.0422 \\
.0203\end{array}$ \\
\hline $\begin{array}{l}550 \\
560 \\
570 \\
580 \\
590\end{array}$ & $\begin{array}{l}.0010 \\
.0018 \\
.0013 \\
.0001 \\
.0000\end{array}$ & $\begin{array}{l}.0026 \\
.0046 \\
.0033 \\
.0003 \\
.0000\end{array}$ & & $\begin{array}{l}.0716 \\
.1080 \\
.1493 \\
.1772 \\
.1894\end{array}$ & $\begin{array}{r}.4007 \\
.6044 \\
.8355 \\
.9917 \\
1.0599\end{array}$ & $\begin{array}{r}.4334 \\
.5945 \\
.7621 \\
.9163 \\
1.0263\end{array}$ & $\begin{array}{l}.4925 \\
.4938 \\
.4692 \\
.4263 \\
.3716\end{array}$ & $\begin{array}{r}1.0011 \\
1.0037 \\
0.9537 \\
.8665 \\
.7554\end{array}$ & $\begin{array}{l}.9950 \\
.9950 \\
.9520 \\
.8700 \\
.7570\end{array}$ & $\begin{array}{l}.0036 \\
.0058 \\
.0049 \\
.00113 \\
.00021\end{array}$ & $\begin{array}{l}.0438 \\
.0706 \\
.0596 \\
.0138 \\
.0026\end{array}$ & $\begin{array}{l}.0087 \\
.0039 \\
.0021 \\
.0017 \\
.0011\end{array}$ \\
\hline $\begin{array}{l}600 \\
610 \\
620 \\
630 \\
640\end{array}$ & & & & $\begin{array}{l}1840 \\
.1656 \\
.1374 \\
.1078 \\
.0778\end{array}$ & $\begin{array}{r}1.0297 \\
0.9267 \\
.7689 \\
.6033 \\
.4354\end{array}$ & $\begin{array}{r}1.0622 \\
1.0026 \\
0.8544 \\
.6424 \\
.4479\end{array}$ & $\begin{array}{l}.3077 \\
.2443 \\
.1832 \\
.1297 \\
.0853\end{array}$ & $\begin{array}{l}.6255 \\
.4966 \\
.3724 \\
.2636 \\
.1734\end{array}$ & $\begin{array}{l}.6310 \\
.5030 \\
.3810 \\
.2650 \\
.1750\end{array}$ & $\begin{array}{l}.00013 \\
.00010 \\
.00007 \\
.00003 \\
.00001\end{array}$ & $\begin{array}{l}.0016 \\
.0012 \\
.0008 \\
.0004 \\
.0001\end{array}$ & $\begin{array}{l}.0008 \\
.0003 \\
.0002 \\
.0000\end{array}$ \\
\hline $\begin{array}{l}650 \\
660 \\
670 \\
680 \\
690\end{array}$ & & & & $\begin{array}{l}.0531 \\
.0338 \\
.0212 \\
.0121 \\
.0067\end{array}$ & $\begin{array}{l}.2972 \\
.1892 \\
.1186 \\
.0677 \\
.0375\end{array}$ & $\begin{array}{l}.2835 \\
.1649 \\
.0874 \\
.0468 \\
.0227\end{array}$ & $\begin{array}{l}.0544 \\
.0316 \\
.0171 \\
.0090 \\
.0043\end{array}$ & $\begin{array}{l}.1106 \\
.0642 \\
.0348 \\
.0183 \\
.0087\end{array}$ & $\begin{array}{l}.1070 \\
.0610 \\
.0320 \\
.0170 \\
.0032\end{array}$ & $\begin{array}{l}.00001 \\
.00001 \\
.00002 \\
.00005 \\
.00012\end{array}$ & $\begin{array}{l}.0001 \\
.0001 \\
.0003 \\
.0006 \\
.0015\end{array}$ & \\
\hline $\begin{array}{l}700 \\
710 \\
720 \\
730 \\
740\end{array}$ & & & & $\begin{array}{l}.0035 \\
.0019 \\
.0010 \\
.0001 \\
.0000\end{array}$ & $\begin{array}{l}.0196 \\
.0106 \\
.0056 \\
.0006 \\
.0000\end{array}$ & $\begin{array}{l}.0114 \\
.0058 \\
.0029 \\
.0014 \\
.0007\end{array}$ & $\begin{array}{l}.0013 \\
.0006 \\
.0003 \\
.0001 \\
.0001\end{array}$ & $\begin{array}{l}.0026 \\
.0012 \\
.0006 \\
.0002 \\
.0002\end{array}$ & $\begin{array}{l}.0041 \\
.0021 \\
.0010 \\
.0005 \\
.0003\end{array}$ & $\begin{array}{l}.00019 \\
.00016 \\
.00013 \\
.00010 \\
.00008\end{array}$ & $\begin{array}{l}.0023 \\
.0020 \\
.0016 \\
.0012 \\
.0010\end{array}$ & \\
\hline $\begin{array}{c}750 \\
760 \\
770-830\end{array}$ & & & & & & $\begin{array}{l}.0003 \\
.0002 \\
.0001\end{array}$ & $\begin{array}{l}.0000 \\
.0000\end{array}$ & $\begin{array}{l}.0000 \\
.0000\end{array}$ & $\begin{array}{l}.0001 \\
.0001\end{array}$ & $\begin{array}{l}.00007 \\
.00006 \\
.00020\end{array}$ & $\begin{array}{l}.0009 \\
.0007 \\
.0025\end{array}$ & \\
\hline Sums..... & 0.6971 & 1. 7850 & 1. 7849 & 1. 5901 & 8.8936 & 8.8987 & 5.2569 & 10.6855 & 10.6857 & 0.8751 & 10.6770 & 10.6770 \\
\hline
\end{tabular}

TABLE 2. Measured spectral transmittances, T, and adjusted spectral transmittances for each of the four filters compared to CIE spectral tristimulus values 


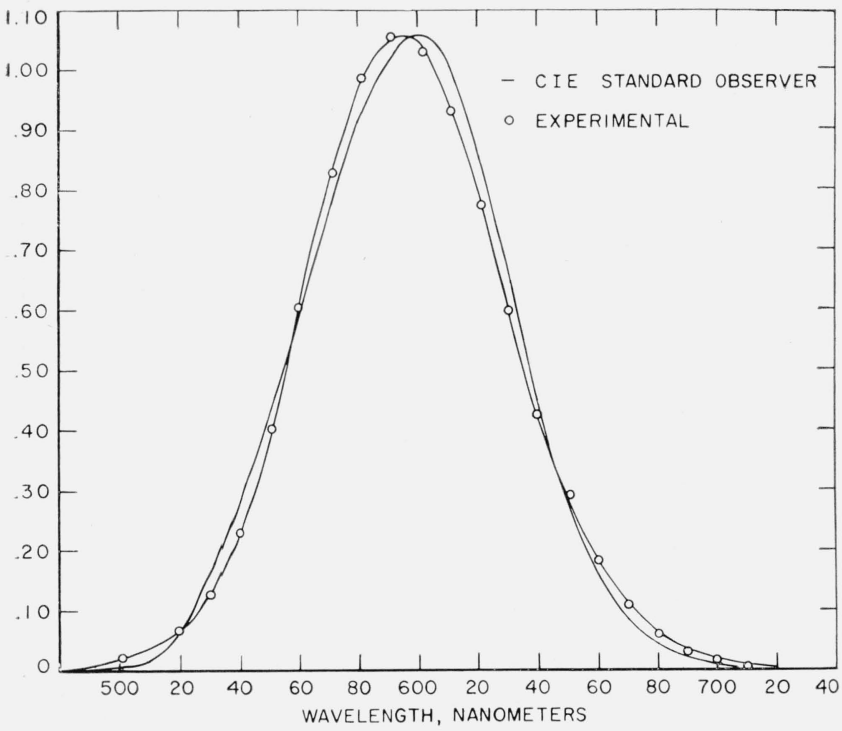

Figure 2. Adjusted transmittance of $\overline{\mathrm{x}}$-long filter compared to CIE tristimulus values $\overline{\mathrm{x}}_{\lambda}$.

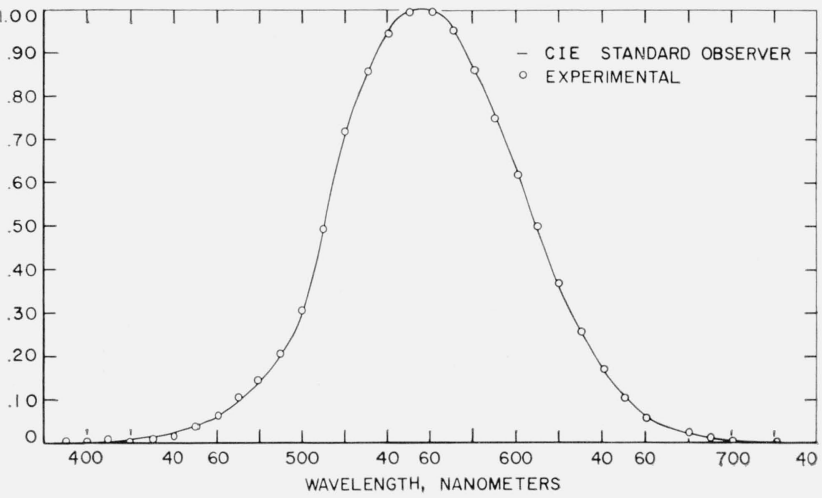

Figure 3. Adjusted transmittance of $\overline{\mathrm{y}}$ filter compared to CIE tristimulus values $\overline{\mathrm{y}}_{\lambda}$.

\section{Performance}

To check the performance of these four colorimeter filters, use was made of the instrument described by Teele [24] which consists essentially of a thermopile, potentiometer, and recorder.

The first check was a measurement of the chromaticity coordinates of an incandescent lamp at a color temperature of $2,854{ }^{\circ} \mathrm{K}$ (CIE source A). The tristimulus values obtained by reducing these data by the factors given above were divided by their sum in the usual way to obtain values of chromaticity coordinates as follows: $x=0.457, y=0.403$, $z=0.140$. These chromaticity coordinates differ from those obtained by computation from the spectral distribution of a Planckian radiator at a temperature of $2,854^{\circ} \mathrm{K}$ by $+0.009,-0.004$, and -0.005 , respectively. These differences correspond to a combination of errors from possible failure of the voltage assigned to the lamp to operate it at a

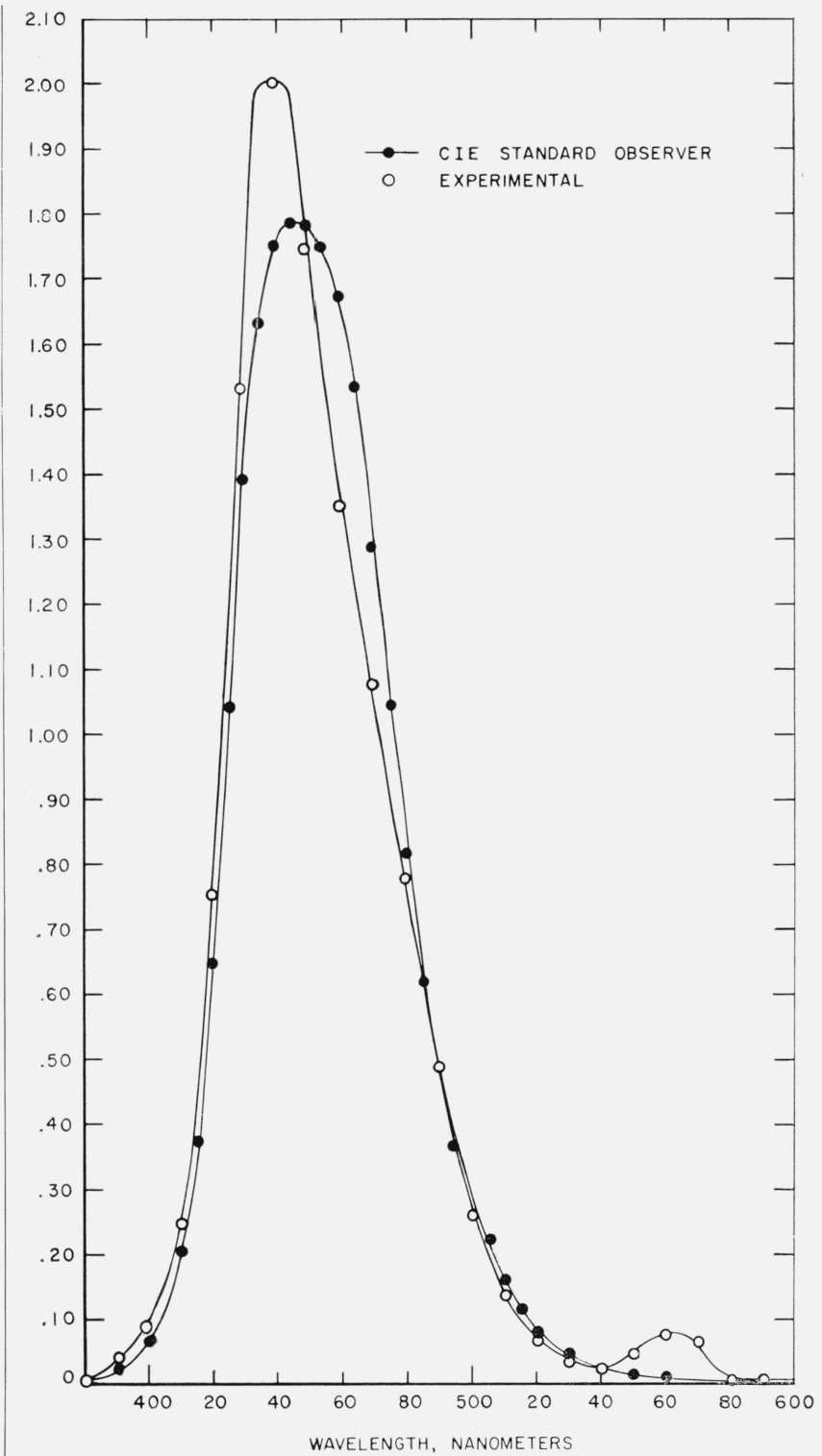

Figure 4. Adjusted transmittance of $\bar{Z}$ filter compared to CIE tristimulus values $\overline{\mathrm{z}}_{\lambda}$.

color temperature of $2,854{ }^{\circ} \mathrm{K}$, from failure of the lamp to yield spectral distributions characteristic of the Planckian radiator, from failure of the colorimeter filters to duplicate the CIE standard observer, and from the experimental errors of reading the thermopile.

A more detailed check of the performance of the colorimeter filters was obtained by measuring five NBS standard spectrophotometer-integrator filters, NBS 2101 through 2105, master set numler 1 . These are glass filters described as selenium reddish orange, carbon yellow, sextant green, cobalt blue, and selective neutral.

They were originally calibrated to check the performance of spectrophotometers equipped with tristimulus integrators. [25] The five filters were measured on two spectrophotometers (Cary 14 and 
GE); appropriate corrections (such as wavelength, zero, $100 \%$, slit width, inertia, and back reflectance) were applied; spectral transmittances were adopted as weighted means; and uncertainties were estimated. The spectral transmittances of these filters are plotted in figure 5 .

To provide a more detailed test of the performance of the colorimeter filters use was made of a device already devised by Teele, which consists essentially of a thermopile (nonselective receiver for radiant energy), potentiometer, and recorder, the incandescent lamp was operated at a color temperature of $2,854^{\circ} \mathrm{K}$ as before. To eliminate back reflection effects, a concave-convex lens was positioned before and another after the filter to be measured as shown in figure 6 . The colorimeter filter, say $\bar{x}$-short, was then introduced between the light source and thermopile, and the reading was recorded. The filter to be measured was placed in the beam between the concave-convex lenses, and a second reading was recorded. This procedure was repeated with each of the four colorimeter filters. The ratios, source through filter to source alone, of such readings through the four colorimeter filters, $\bar{x}$-short, $\bar{x}$-long,

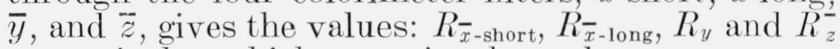
respectively, which may in themselves serve as a colorimetric specification of the filter to be measured relative to the reference source. The CIE tristimulus values of the test filter with source $A$, adjusted to make $Y_{\mathrm{A}}$ equal to the luminous transmittance of the filter in percent, are computed as follows:

$$
\begin{aligned}
& X_{\mathrm{A}}=5.37 R_{\bar{x} \text {-short }}+104.45 R_{\bar{x} \text {-long }}, \\
& Y_{\mathrm{A}}=100.00 R_{\bar{y}}, \\
& Z_{\mathrm{A}}=35.55 R_{\bar{z}},
\end{aligned}
$$

where the coefficients $5.37,104.45,100.00$, and 35.55 are related to the source- $A$ tristimulus values. The coefficients of $R^{-}$and $R_{z}^{-}$, are the $Y$ and $Z$ tristimulus values for source $A$, respectively. The coefficients of $R_{\bar{x} \text {-short }}$ and $R_{\bar{x} \text {-long }}$ are the summations of the spectral tristimulus values for the $\bar{x}$ function and source A from 380 to $500 \mathrm{~nm}$ and from 510 to $770 \mathrm{~nm}$, respectively.

The chromaticity coordinates, $x, y, z$, of the test filters are calculated from the tristimulus values, $X$, $Y, Z$, in the usual manner:

$x=X /(X+Y+Z), y=Y /(X+Y+Z), z=Z /(X+Y+Z)$

Table 3 compares the measured values of the five standard filters with their assigned values. Each measured value was computed from 10 independent determinations of the ratio $R$. The uncertainties of the as igned values shown in the table are those estimated by Keegan, Schleter, and Judd as the ranges of the values found by three different spectrophotometers [25]; see their table 11 . The uncertainties shown for the measured values are based upon computations of huge error (4.9 times the probable error) of the mean of the ten settings of the ratios $R$. These compui tions showed that the huge error (uncer-

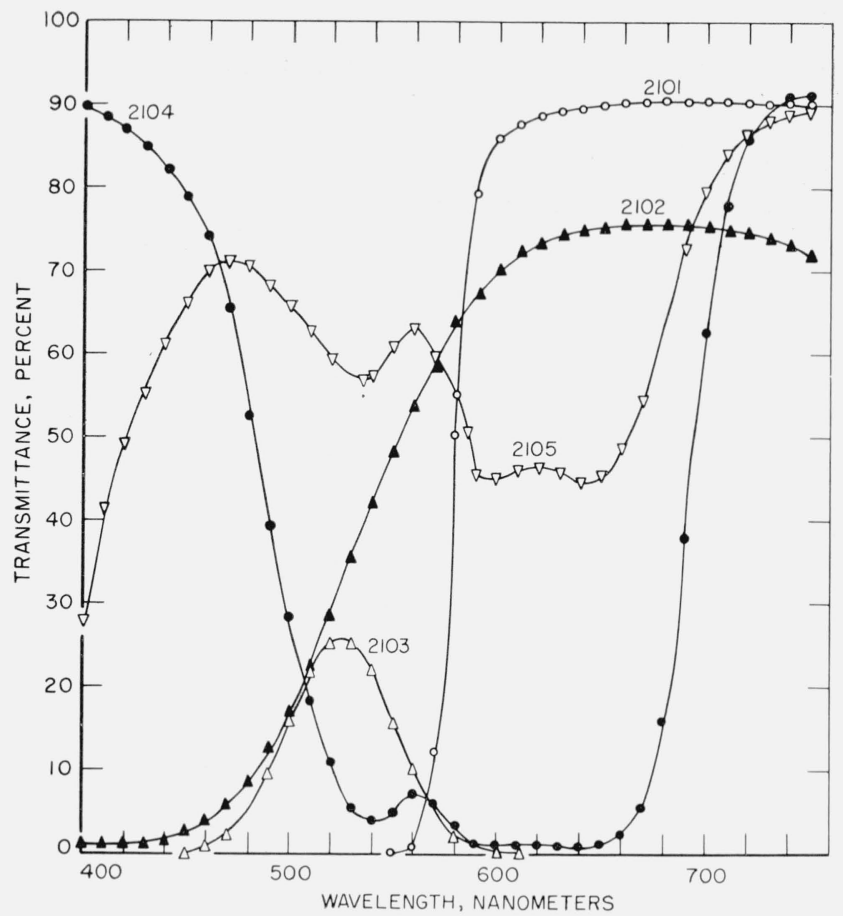

Figure 5. Spectial transmittances of the five test filters.

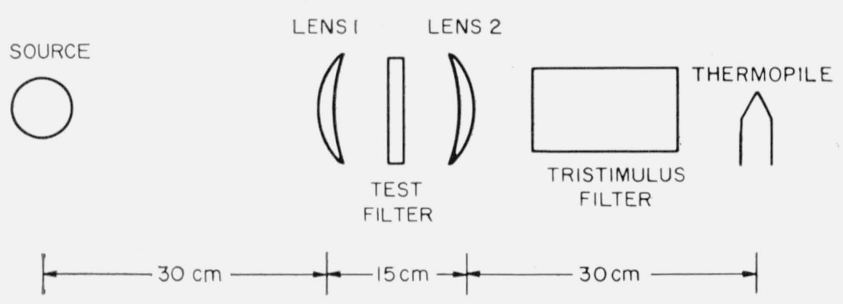

Figure 6. Diagram of the optical arrangement.

tainty at the one-tenth of one percent level) of values of the ratio $R$ was on the average equal to \pm 0.0025 , and these estimates of uncertainty are given directly for the values of $Y$ in table 3 . Fropagation of these errors to chromaticity coordinates, $x, y, z$, leads to the estimates of uncertainties entered in table 3.

It will be noted from table 3 that the sum of the uncertainties listed fails in 11 cases out of 20 to exceed the difference between the measured and assigned values. Of course, since the colorimeter filters do not succeed precisely in duplicating the distribution functions of the 1931 CIE standard observer (see table 2), some discrepancy between measured and assigned values is to be expected. Table 4 gives in column 2 the differences ascribable to failure of the spectral transmittances of the colorimeter flters to have precisely the wavelength variation striven for. In column 3 are given the observed differences copied from the last column of table 3 , and in column 4 are given the sums of the uncertainties listed in columns 2 and 3 of table 3 . If the expected difference departs from the observed difference by less than the combined uncertainty, we may say that a reasonable basis for explaining the discrepancy has been found. Column 5 gives the amounts of the unexplained discrepancies. It is computed as the excess of the abso- 
lute value of the difference between columns 2 and 3 over the sum of the uncertainties in column 4 . If there is no excess, no entry is inserted.

TABLE 3. Comparison of measured and assigned values of chromaticity coordinates, $\mathrm{x}, \mathrm{y}, \mathrm{z}$, and luminous transmittance, $Y$, for CIE source A for the five NBS standard filters

\begin{tabular}{|c|c|c|c|}
\hline \multirow{2}{*}{$\begin{array}{l}\text { Filter No. } \\
\text { and } \\
\text { coordinate }\end{array}$} & \multicolumn{2}{|c|}{$\begin{array}{l}\text { CIE colorimetric coordinates for } \\
\text { standard filters with source A }\end{array}$} & \multirow{2}{*}{ Difference } \\
\hline & Measured & Assigned & \\
\hline $\begin{array}{c}2101 \\
x \\
y \\
z \\
Y\end{array}$ & $\begin{array}{r}0.6364 \pm 0.0018 \\
.3577 \pm .0018 \\
.0059 \pm .0018 \\
38.0 \pm .25\end{array}$ & $\begin{array}{r}0.6488 \pm 0.0009 \\
.3509 \pm .0009 \\
.0003 \pm .0000 \\
37.6 \pm .5\end{array}$ & $\begin{array}{l}-0.0124 \\
+.0068 \\
+.0056 \\
+.4\end{array}$ \\
\hline $\begin{array}{c}2102 \\
x \\
y \\
z \\
Y\end{array}$ & $\begin{array}{r}0.5443 \pm 0.0015 \\
.4298 \pm .0014 \\
.0260 \pm .0007 \\
55.1 \pm .25\end{array}$ & $\begin{array}{r}0.5497 \pm 0.0002 \\
.4324 \pm .0003 \\
.0179 \pm .0001 \\
55.3 \pm .02\end{array}$ & $\begin{array}{l}-0.0054 \\
-.0026 \\
+.0081 \\
-.2\end{array}$ \\
\hline $\begin{array}{c}2103 \\
x \\
y \\
z \\
Y\end{array}$ & $\begin{array}{l}0.253 \pm 0.016 \\
.654 \pm .015 \\
.093 \pm .003 \\
8.56 \pm .25\end{array}$ & $\begin{array}{l}0.236 \pm 0.005 \\
.668 \pm .004 \\
.096 \pm .004 \\
9.07 \pm .13\end{array}$ & $\begin{array}{r}+0.017 \\
-.014 \\
-.003 \\
-.01\end{array}$ \\
\hline $\begin{array}{c}2104 \\
x \\
y \\
z \\
Y\end{array}$ & $\begin{array}{c}0.1992 \pm 0.0060 \\
.1609 \pm .0059 \\
.6399 \pm .0064 \\
5.8 \pm .25\end{array}$ & $\begin{array}{r}0.1871 \pm 0.0019 \\
.1630 \pm .0034 \\
.6499 \pm .0057 \\
5.9 \pm .23\end{array}$ & $\begin{array}{r}+0.0121 \\
-.0021 \\
-.0100 \\
-.1\end{array}$ \\
\hline $\begin{array}{c}2105 \\
x \\
y \\
z \\
Y^{y}\end{array}$ & $\begin{array}{r}0.4211 \pm 0.0014 \\
.4076 \pm .0014 \\
.1712 \pm .0005 \\
53.3 \pm .25\end{array}$ & $\begin{array}{r}0.4163 \pm 0.0019 \\
.4087 \pm .0020 \\
.1750 \pm .0016 \\
53.9 \pm .2\end{array}$ & $\begin{array}{c}+0.0048 \\
-.0011 \\
-.0038 \\
-.6\end{array}$ \\
\hline
\end{tabular}

TABLE 4. Analysis of the discrepancies between the differences listed in table 3 and those to be expected from the actual colorimeter filters used.

\begin{tabular}{|c|c|c|c|c|}
\hline $\begin{array}{c}\text { Filter } \\
\text { No. and } \\
\text { coordinate }\end{array}$ & $\begin{array}{c}\text { Differences } \\
\text { to be } \\
\text { expected } \\
\text { between } \\
\text { measured } \\
\text { and assigned } \\
\text { values }\end{array}$ & $\begin{array}{l}\text { Differences } \\
\text { actually } \\
\text { found } \\
\text { (taken from } \\
\text { last column } \\
\text { of table } 3 \text { ) }\end{array}$ & $\begin{array}{l}\text { Sum of the } \\
\text { uncertainties } \\
\text { in the assign- } \\
\text { ed and meas- } \\
\text { ured values } \\
\text { (from col- } \\
\text { umns } 2 \text { and } \\
3 \text { of table } 3 \text { ) }\end{array}$ & $\begin{array}{l}\text { Unexplained discrep- } \\
\text { ancies. (If the absolute } \\
\text { value of the difference } \\
\text { between columns } 2 \\
\text { and } 3 \text { exceeds the sum } \\
\text { of the uncertainties in } \\
\text { column } 4 \text {, the amount } \\
\text { of this excess is recorded } \\
\text { below.) }\end{array}$ \\
\hline (1) & (2) & (3) & (4) & (5) \\
\hline $\begin{array}{c}2101 \\
x \\
y \\
z \\
Y\end{array}$ & $\begin{array}{r}-0.0023 \\
-.0015 \\
+.0038 \\
-.2\end{array}$ & $\begin{array}{l}-0.0124 \\
+.0068 \\
+.0056 \\
+.4\end{array}$ & $\begin{array}{l}0.0027 \\
.0027 \\
.0008 \\
.75\end{array}$ & $\begin{array}{r}0.0074 \\
.0056 \\
.0010\end{array}$ \\
\hline $\begin{array}{c}2102 \\
x \\
y \\
z \\
Y\end{array}$ & $\begin{array}{c}-0.0032 \\
-.0042 \\
+.0073 \\
-.1\end{array}$ & $\begin{array}{l}-0.0054 \\
-.0026 \\
+.0081 \\
-.2\end{array}$ & $\begin{array}{l}0.0017 \\
.0017 \\
.0008 \\
.27\end{array}$ & 0.0005 \\
\hline $\begin{array}{c}2103 \\
x \\
y \\
z \\
Y\end{array}$ & $\begin{array}{l}-0.0009 \\
-.0010 \\
+.0020 \\
+.02\end{array}$ & $\begin{array}{l}+0.017 \\
-.014 \\
-.003 \\
-.51\end{array}$ & $\begin{array}{l}0.021 \\
.019 \\
.007 \\
.38\end{array}$ & 0.15 \\
\hline $\begin{array}{c}2104 \\
x \\
y \\
z \\
Y\end{array}$ & $\begin{array}{r}+0.0096 \\
+.0003 \\
+.0099 \\
+.01\end{array}$ & $\begin{array}{l}+0.0121 \\
-.0021 \\
-.0100 \\
-.1\end{array}$ & $\begin{array}{l}0.0079 \\
.0093 \\
.0121 \\
.48\end{array}$ & \\
\hline $\begin{array}{c}2105 \\
x \\
y \\
z \\
Y\end{array}$ & $\begin{array}{c}+0.0025 \\
-.0017 \\
-.0007 \\
.0\end{array}$ & $\begin{array}{c}+0.0048 \\
-.0011 \\
-.0038 \\
-.6\end{array}$ & $\begin{array}{l}0.0033 \\
.0034 \\
.0021 \\
.45\end{array}$ & $\begin{array}{c}0.0010 \\
.15\end{array}$ \\
\hline
\end{tabular}

Table 4 shows that nearly all discrepancies are accounted for by the imperfection of the fit of the four filters to the respective CIE curves and that improvement in performance depends upon finding better constitutents for the solutions and different glasses (or different thicknesses of the same glasses that are now used).

It will be noted from table 4 that for four of the five filters the unexplained discrepancies (column 5) are few and small. For filter 2101, however, the discrepancies in chromaticity coordinates are large. Perhaps it is significant that this filter (selenium reddish orange) is the only one of the five which has a large temperature coefficient of spectral transmittance.

By comparing the uncertainties in the measured values (column 3 , table 3 ) ascribable to the uncertainty of 2.5 on a scale of a thousand in the measured ratios with the differences (column 2 , table 4 ) to be expected because the colorimeter filters do not have precisely the ideal spectral character striven for, it may be noted that those two sources of error are about equally important. The performance of the colorimeter could be significantly improved only by developing better $\bar{x}$ and $\bar{z}$ colorimeter filters and at the same time reducing the noise from the thermopile and amplifier. Significant improvement of the colorimeter filters might be accomplished by combining the components in parallel as well as in series as was originally suggested by Dresler [26], and used among others by Nimeroff and Wilson [15], Frühling and Krempel [27], Geutler [28], and Davies and Wyszecki [29].

The authors express their appreciation to the members of the staff who ran the numerous spectrophotometric curves required to develop the filters.

\section{References}

[1] H. E. Ives, A precision artificial eye, Phys. Rev. 6, 334 (1915).

[2] F. Twyman and J. Perry, Improvements in or relating to colorimeters, Brit. Pat. Spec. No. 324, 351 (Jan. 20, 1930).

[3] J. Guild, The instrumental side of colorimetry, J. Sci. Instr. 11, 68 (1934).

[4] G. T. Winch and E. H. Palmer, A direct reading photoelectric trichromatic colorimeter, Trans. Illum. Eng. Soc. London $\boldsymbol{2}, 137$ (1937).

[5] A. Dresler and H. G. Frühling, A tristimulus photoelectric colorimeter (in German), Das Licht 8, 238 (1938)

[6] B. T. Barnes, A four-filter photoelectric colorimeter, J Opt. Soc. Am. 29, 448 (1939).

[7] K. S. Gibson, Photoelectric photometers and colorimeters, Instruments 9, 309 and 335 (1936).

[8] J. A. Van den Akker, Chromaticity limitations of the best physically realizable three-filter photoelectric colorimeters, J. Opt. Soc. Am. 27, 401 (1937).

[9] R. S. Hunter, Photoelectric tristimulus colorimetry with three filters, NBS Circ. C429 (1942).

[10] R. S. Hunter, A multipurpose photoelectric reflectometer, J. Res. NBS 25, 581 (1940) RP1345; or J. Opt. Soc. Am. 30, 536 (1940).

[11] L. G. Glasser and D. J. Troy, A new high sensitivity colorimeter, J. Opt. Soc. Am. 4\%, 652 (1952).

[12] R. S. Hunter, Photoelectric color difference meter, J. Opt. Soc. Am. 48, 985 (1958). 
[13] C. G. Sziklai, A tristimulus photometer, J. Opt. Soc. Am. 41, 321 (1951).

[14] G. P. Bentley, An industrial color matcher, Electronics 24, 102 (1951).

[15] I. Nimeroff and S. W. Wilson, A colorimeter for pyrotechnic smokes, J. Res. NBS 52, 195 (1954) RP2488.

[16] H. E. Ives and E. F. Kingsbury, Experiments with colored absorbing solutions for use in hetrochromatic photometry, Trans. Illum. Eng. Soc. 8, 795 (1914).

[17] H. E. Ives and E. F. Kingsbury, Additional experiments on colored absorbing solutions for use in hetrochromatic photometry, Trans. Illum. Eng. Soc. 10, 253 (1915).

[18] H. E. Ives, The photometric scale, J. of Franklin Inst. 188, 217 (1919).

[19] K. S. Gibson, R. P. Teele, and H. J. Keegan, An improved luminosity filter, J. Opt. Soc. Am. 29, 144 (1939).

[20] A. C. Hardy, A new recording spectrophotometer, J. Opt. Soc. Am. 25, 305 (1935).

[21] K. S. Gibson and H. J. Keegan, Calibration and operation of the General Electric recording spectrophotometer of the National Bureau of Standards, J. Opt. Soc. Am. 28, 372 (1938).

[22] H. J. Keegan and K. S. Gibson, On the use of working standards of didymium and vitrolite glasses for spectrophotometric measurements, J. Opt. Soc. Am. 34, 770 (1944).
[23] K. S. Gibson, Spectrophotometry, NBS Circ. 484 (1949).

[24] R. P. Teele, A physical photometer, J. Res. NBS 27 , 217 (1941) RP 1415; also R. P. Teele, Measuring circuit for radiometers, J. Opt. Soc. Am. 44, 860 (1954).

[25] H. J. Keegan, J. C. Schleter, and D. B. Judd, Glass filters for checking performance of spectrophotometerintegrator systems of color measurement, J. Res. NBS 66A (Phys. and Chem.) No. 3, 203 (1962).

[26] A. Dresler, On a new kind of filter combination for exact adjustment of the spectral sensitivity of photocells to the eye-sensitivity curve (in German), Das Licht, 3, 41 (1933)

[27] H. G. Frühling and F. Krempel, A photoelectric colorimeter constructed according to the Dresler principle (in German), Die Farbe, 3, 1 (1955).

[28] G. Geutler, On the improvement and use of photoelectric colorimeters according to the Dresler principle, Die Farbe, \%, 1953 (1958).

[29] W. E. R. Davies and G. Wyszecki, Physical approximation of color-mixture functions, J. Opt. Soc. Am. 52, 679 (1962).

(Paper 67C4-143) 